\title{
ASSESSMENT OF RADON GAS CONCENTRATIONS LEVELS AND HAZARDS INDICES IN HOUSES OF WASSIT PROVINCE- IRAQ
}

\author{
Laith Ahmed Najam ${ }^{1, *}$, Taghreed Khalid Hameed ${ }^{2}$ and Ahmed Obeed \\ Farhan $^{3}$ \\ ${ }^{1}$ Department of Physics, College of Science, Mosul University, Mosul, Iraq \\ ${ }^{2}$ Department of Physics, College of Education, Al-Mustansiriyah University, Iraq \\ ${ }^{3}$ Center of desert studies in Anbar province, Iraq \\ *E-mail: prof.lai2014@gmail.com
}

ABSTRACT

In this work a set of indoor Rn-222 measurements have been carried out in various houses in Wassit province. Rn222 concentrations were the measurement by using rad-7 detector. The results show that, the highest Rn-222 concentration in indoor houses was found in Nuamaniya district which was $\left(121 \mathrm{~Bq} / \mathrm{m}^{3}\right)$, while the lowest Rn-222 concentration was found in Badra district which was $\left(49 \mathrm{~Bq} / \mathrm{m}^{3}\right)$, which is less than the recommended range (200$300 \mathrm{~Bq} / \mathrm{m}^{3}$ ), the hazard indices values were lower than the permissibility limit value.

Keywords: Rad-7 detector, Rn-222 gas, Wassit province.

(C) RASĀYAN. All rights reserved

\section{INTRODUCTION}

Gaseous radioactive $\mathrm{Rn}-222$ gas, a decay product of Ra-226 isotope is present in all the types of rock and soil. Ra-226 atoms decay in soil particles, the resulting atoms of Rn-222 entering to air-filled pores and then transported by advection and diffusion through this space in order to exhale into the atmosphere. ${ }^{1}$ $\mathrm{Rn}-222$ concentrations in soil gas within a few meters of the surface ground are obviously important in determining radon rates of entry into pore spaces and then into atmosphere. ${ }^{2}$ The measurement of Rn-222 concentration in soil gas, in principle, can be used as a method of evaluating the potential for elevated indoor $\mathrm{Rn}-222$ concentrations. ${ }^{3} \mathrm{Rn}-222$ gas can diffuse easily out of surface soil into houses or air; it can be trapped in poorly ventilated houses and so its concentration can build up to higher levels. Although soil is considered to be the main source of indoor radon concentration, raw building materials (cement, gravel, especially, etc.) can make a significant contribution to the level of natural radioactivity in closed spaces such as stores and badly ventilated houses. Moreover, the production rate of Rn-222 in houses depends on the concentration of Ra-226 content in the subsoil, building materials, and porosity as well as that the density of the wall materials. The emission of $\mathrm{Rn}-222$ from the building materials is found to be a function of ventilation as well as of the Ra-226 content in building materials. The nongaseous Rn-222 decay products are partially hanging in air as a mixture of attached and detached fractions and partly deposited on walls and furniture. ${ }^{4}$

In this work, Rad-7 detector will be used to determine the Rn-222 concentration and measure hazard indices in houses selected districts in Wassit province because there is no studying of radon gas concentration in this institute.

\section{Description of Study Area}

Wassit province is located in eastern Iraq, on the border with the Islamic Republic of Iran. Wassit shares internal boundaries with the provinces of Qadissiya, Baghdad, Missan, Babil, Thiqar and Diyala as shown in (Fig.-1). Wassit province is intersected by the Tigris River, along which a bar of irrigated farmland 
runs, giving way to a dry desert landscape to the northeast. Wassit has a dry, desert climate, with temperatures readily override $46^{\circ} \mathrm{C}$ in summer.

\section{EXPERIMENTAL}

The interior cell of the RAD-7 detector is a hemisphere with volume about of $0.72 \mathrm{~L}$. When the Rn- 222 and Rn-220 daughters, deposited on the surface of detector, decay, they emit alpha particles of characteristic energy directly into the solid state detector. The accumulations of many signals result in a spectrum. The RAD-7 draws air from the environment through desiccant and inlet filter into the measurement chamber. ${ }^{5}$ RAD-7 was linked with tubing and desiccant to absorb the humidity as shown in as shown in (Fig.-2).

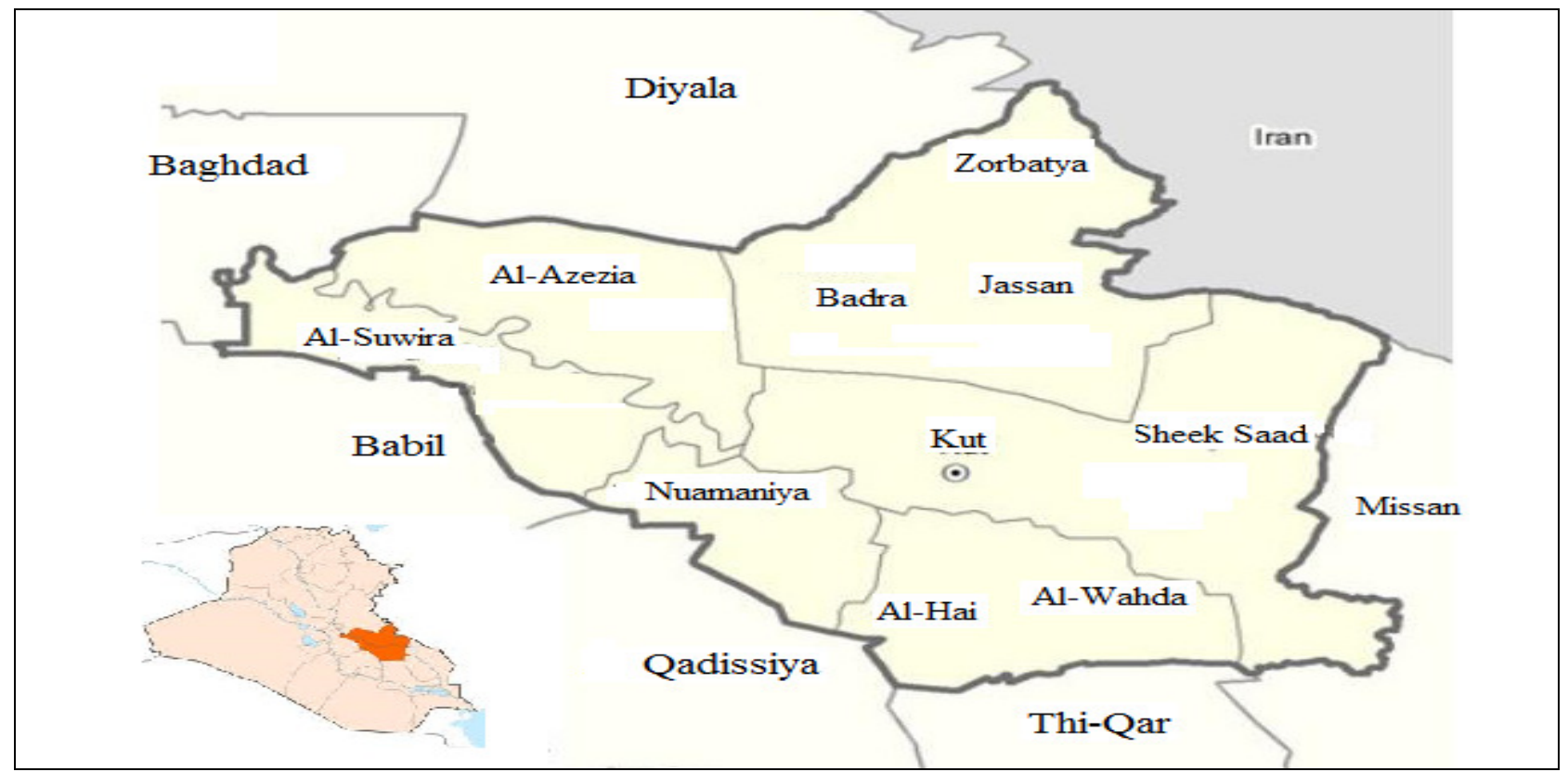

Fig.-1: Study Area

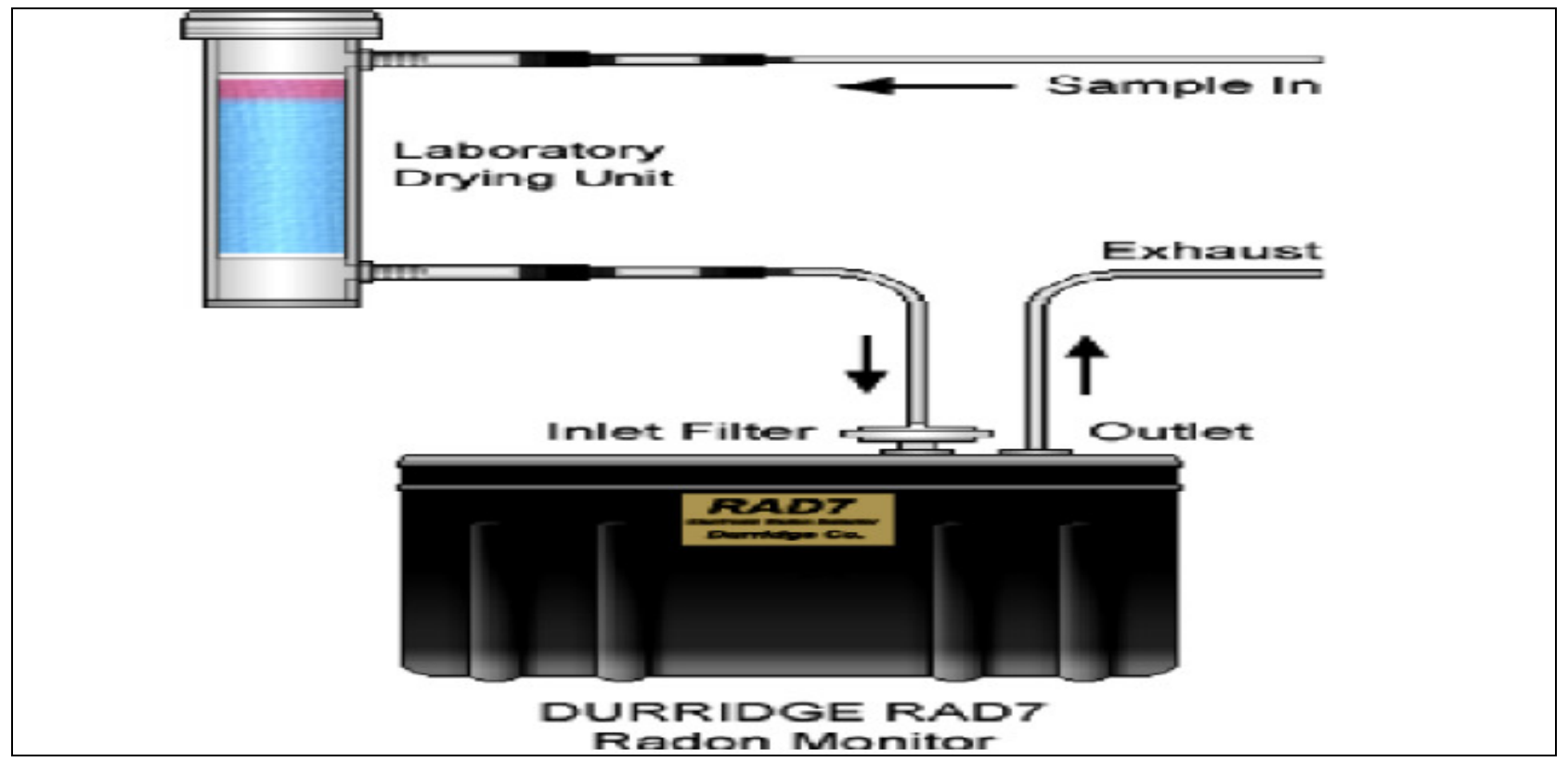

Fig.-2: RAD-7 Detector 
RASĀYAN $J$. Chem.

Vol. 10 | No. 4 |1311-1315 | October - December | 2017

\section{Measurements of hazard indices}

1. The Potential Alpha Energy Concentration (PAEC) $)^{6-8}$ :

$\operatorname{PAEC}(\mathrm{WL})=\mathrm{F} \times \mathrm{C}_{\mathrm{Rn}} / 3700$

Where $(\mathrm{F}=0.4)(\mathrm{UNSCEAR}, 2000)^{9}$

2. Exposure to Rn-222 progeny $\left(\mathrm{E}_{\mathrm{P}}\right)^{10}$ :

$\mathrm{E}_{\mathrm{P}}\left(\mathrm{WLM} \mathrm{Y} \mathrm{Y}^{-1}\right)=8760 \times \mathrm{n} \times \mathrm{F} \times \mathrm{C}_{\mathrm{Rn}} / 3700 \times 170$

Where $\mathrm{C}_{\mathrm{Rn}}\left(\mathrm{Bq} \cdot \mathrm{m}^{-3}\right), \mathrm{n}=(0.8), 8760$ is the number of hours per year ,170 is the number of hours per working month .

3. The annual effective dose (AED) ${ }^{11-13}$ :

$\operatorname{AED}(\mathrm{m} \mathrm{Sv} / \mathrm{y})=\mathrm{C}_{\mathrm{Rn}} \times \mathrm{F} \times \mathrm{H} \times \mathrm{T} \times \mathrm{D}$

Where $\mathrm{F}$ is $=(0.4),(\mathrm{H})=(0.8), \mathrm{T}=8760 \mathrm{~h} / \mathrm{y}),(\mathrm{D})=\left[9 \times 10^{-6}(\mathrm{~m} \mathrm{~Sv}) /\left(\mathrm{Bq} . \mathrm{m}^{-3} \cdot \mathrm{h}\right)\right]$.

4. The lung cancer cases per year per million person (CPPP), ${ }^{14,15}$ :

$(\mathrm{CPPP})=\mathrm{AED} \times\left(18 \times 10^{-6} \mathrm{mSv}^{-1} \cdot \mathrm{y}\right)$

\section{RESULTS AND DISCUSSION}

In this work indoor Rn-222 concentrations, were a measurement in various compartments for ten various houses in Wassit province in May and June of 2017. Table-1 summarizes the Rn-222 concentrations in indoor houses in various sites in Wassit province. From Table-1 it can note that, the highest Rn-222 concentration in indoor houses was found in Nuamaniya district $\left(121 \mathrm{~Bq} / \mathrm{m}^{3}\right)$, while the lowest Rn-222 concentration was found in Badra district $\left(49 \mathrm{~Bq} / \mathrm{m}^{3}\right)$, see (Figure-3), with an average value (79.6 \pm 17.8$)$, which is less than the recommended range $\left(200-300 \mathrm{~Bq} / \mathrm{m}^{3}\right)^{15}$, the less value for indoor radon concentrations might be due to good ventilation conditions of the houses.

The highest value of (PAEC) was found in Nuamaniya district which was $(0.013081 \mathrm{mWL})$, while the lowest value of (PAEC) was found in Badra district which was $(0.005297 \mathrm{mWL})$ with an average value $(0.009 \pm 0.001 \mathrm{mWL})$, which is less than the recommended value $(53.33 \mathrm{mWL}){ }^{16}$

The highest value of $\left(\mathrm{E}_{\mathrm{P}}\right)$ was found in Nuamaniya district $\left(0.53966 \mathrm{WLMY}^{-1}\right)$, while the lowest value of $\left(\mathrm{E}_{\mathrm{P}}\right)$ was found in Badra district $\left(0.21854 \mathrm{WLMY}^{-1}\right)$, with an average value $\left(0.355 \pm 0.07 \mathrm{WLMY}^{-1}\right)$, which is less than the recommended range $\left(1-2 \mathrm{WLMY}^{-1}\right){ }^{6}$

Table-1: Rn-222 concentration $\left(\mathrm{C}_{\mathrm{Rn}}\right),(\mathrm{PAEC}),\left(\mathrm{E}_{\mathrm{P}}\right),(\mathrm{AED}),(\mathrm{CPPP})$ in houses in Wassit province.

\begin{tabular}{c|c|c|c|c|c|c}
\hline No. & District & $\begin{array}{c}\text { Mean of } \\
\mathrm{C}_{\mathrm{Rn}} \\
\left(\mathrm{Bq} / \mathrm{m}^{3}\right)\end{array}$ & $\begin{array}{c}\text { PAEC } \\
(\mathrm{m} \mathrm{WL})\end{array}$ & $\begin{array}{c}\left(\mathrm{E}_{\mathrm{P}}\right) \\
\left(\mathrm{WLM} \mathrm{Y}^{-1}\right)\end{array}$ & $\begin{array}{c}(\mathrm{AED}) \\
(\mathrm{mSv} / \mathrm{y})\end{array}$ & $\begin{array}{c}\text { Lung Cancer } \\
110^{6} \text { person }\end{array}$ \\
\hline 1 & Kut & 91 & 0.009838 & 0.40586 & 2.2932 & 41.2776 \\
\hline 2 & Al-Hai & 65 & 0.007027 & 0.2899 & 1.638 & 29.484 \\
\hline 3 & Al-Suwira & 81 & 0.008757 & 0.36126 & 2.0412 & 36.7416 \\
\hline 4 & Zorbatya & 83 & 0.008973 & 0.37018 & 2.0916 & 37.6488 \\
\hline 5 & Al-Azezia & 104 & 0.011243 & 0.46384 & 2.6208 & 47.1744 \\
\hline 6 & Nuamaniya & 121 & 0.013081 & 0.53966 & 3.0492 & 54.8856 \\
\hline 7 & Jassan & 87 & 0.009405 & 0.38802 & 2.1924 & 39.4632 \\
\hline 8 & Badra & 49 & 0.005297 & 0.21854 & 1.2348 & 22.2264 \\
\hline 9 & Al-Wahda & 62 & 0.006703 & 0.27652 & 1.5624 & 28.1232 \\
\hline 10 & Sheek Saad & 53 & 0.00573 & 0.23638 & 1.3356 & 24.0408 \\
\hline & Ave. & $79.6 \pm 17.8$ & $0.009 \pm 0.001$ & $0.355 \pm 0.07$ & $2.006 \pm 0.45$ & $36.107 \pm 8.1$ \\
\hline & Min. & 49 & 0.005297 & 0.21854 & 1.2348 & 22.2264 \\
\hline & Max. & 121 & 0.013081 & 0.53966 & 3.0492 & 54.8856 \\
\hline & Worldwide & $200-300$ & 53.33 & $1-2$ & 370 & 55 \\
\hline & average & & & & &
\end{tabular}


Also from Table-1, it can be noticed that, the highest value of (AED) was found in Nuamaniya district (3.0492 mSv/y), while the lowest value of (AED) was found in Badra district $(1.2348 \mathrm{mSv} / \mathrm{y})$, with an average value $(2.006 \pm 0.45 \mathrm{mSv} / \mathrm{y})$ which is less than the recommended range $(3-10 \mathrm{mSv} / \mathrm{y}) .{ }^{17}$

Finally, it it can note from Table (1) that the highest value of (CPPP) was found in Nuamaniya district (54.8856), while the lowest value of (CPPP) was found in Badra district (22.2264), with an average value (36.107 \pm 8.1$)$ which is less than the recommended range (170-230) [17]. All results in the present work less than the anthers work in Thiqar and Baghdad province - Iraq. ${ }^{18,19}$

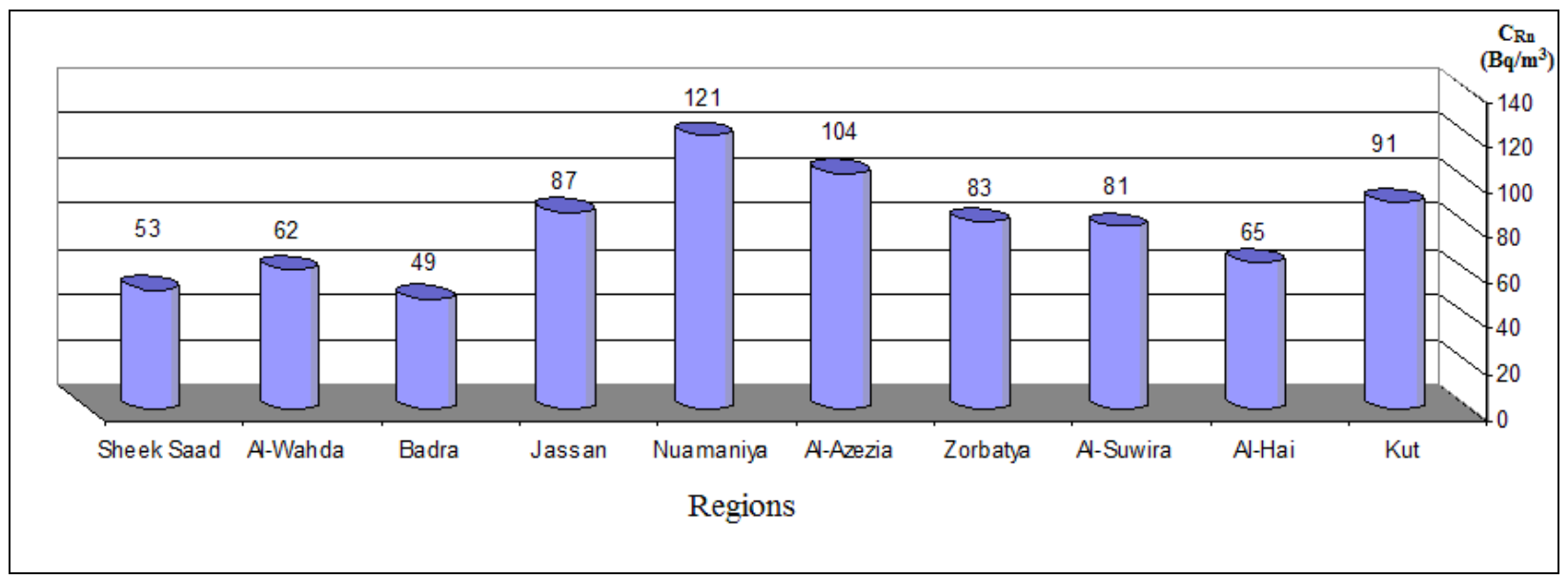

Fig.-3: Radon gas concentration in an indoor house in all districts studied in Wassit province.

\section{CONCLUSION}

In this article, indoor radon concentration level in Wassit province was determined in a total of ten houses. The indoor radon concentration in all values measured in Wassit province is less than the range $\left(200-300 \mathrm{~Bq} / \mathrm{m}^{3}\right.$ ) and the hazard indices (PAEC), ( $\left.\mathrm{E}_{\mathrm{P}}\right),(\mathrm{AED}),(\mathrm{CPPP})$ values were lower than the permissibility limit value, the study shows that indoor air is not dangerous to people in Wassit province.

\section{REFERENCES}

1. A. Abojassim Al-Hamidawi, Science and Technology of Nuclear Installations, 2015, 5(2015).

2. UNSCEAR Annex B. Sources and effects of ionizing radiation. United Nations Scientific Committee on the Effect of Atomic Radiation, United Nations, New York, (2000).

3. D. Iskandar, T. Iida, H. Yamazawa, J. Moriizumi, J. Koarashi, K. Yamasoto, M. Shimo, T. Tsujimoto, S. Ishikawa, M. Fukuda, H. Kojima, Applied Radiation and Isotopes, 63,401 (2005).

4. F. I. Hassan, Al-Najah University Journal for Research, 10(4), 92(1996).

5. Durridge Company Inc., Reference Manual version 6.0.1, RAD-7 Electronic Radon Detector, (2010).

6. A. H. Ismail and M. S. Jaafar, "Bioinformatics and Biomedical Engineering (iCBBE), ldo $4^{\text {th }}$ international Conference in Cheng du ,18-20 June, (2010).

7. A. H. Ismail and Z. A. Hussyin,"Study of seasonal variations of radon levels and its risks inside various schools in Iraqi Kurdistan district for the first time" Proceeding of the $10^{\text {th }}$ International Conference on Environmental Science and Technology", KOS Island, Greece , 5-7 September,B-305B317, (2007).

8. S. Kansal, R. Mehra and N. P. Singh, Applied Radiation and Isotopes, 70,1110 (2012)

9. UNSCEAR. United Nations Scientific Committee on the Effects of Atomic Radiation: Sources and Effects of Ionizing Radiation, 1, United Nations, New York, (2000).

10. ICRP(International Commission on Radiological Protection Publication),Protection against Radon222 at home and at work.Annals of ICRP: Oxford, Pergamum Press,1 (1994). 
RASĀYAN $J$. Chem.

Vol. 10 | No. 4 |1311-1315 | October - December | 2017

11. A. M. Mowlavi, M.R.Fornasier, A. Binesh, and M. Denasier, Iran Environ. Monit. Assess., 184,1085 (2012) .

12. UNSCAER Appendix I: Epidemiological evaluation of radiation induced cancer; Appendix G: Biological effects of low radiation doses, (2000).

13. K. M. Abumurad, and R. A. Al-Omari, Radiation Measurements, 43, S389-S, (2008).

14. H.H. Mansour, Radiation Measurement, 40, 544(2005).

15. A.A. Abdullah, Ph.D. Thesis, Department of Physics, University Sains Malaysia, Malaysia (2013).

16. UNSCEAR, "Genetic and somatic effects of ionizing radiation", United Nations (1993).

17. ICRP, "Protection Against Rn-222 at Home and at Work" International Commission on Radiological Protection Publication, 65, Annals of ICRP 23(2), Pergamum Press; Oxford, (1993).

18. H. L. Mansour, N. F. Tawfiq, M. S. Karim, Journal of Natural Sciences, 2(1), 19 (2014).

19. H. L. Mansour, N. F Tawfiq, M. S. Karim, Journal of Applied Research, 4(2), 35 (2014).

[RJC-1884/2017] 